\title{
Building an integrative model of small business growth
}

\author{
Johan Wiklund · Holger Patzelt · Dean A. Shepherd
}

Accepted: 9 October 2007 / Published online: 8 December 2007

(C) Springer Science+Business Media, LLC. 2007

\begin{abstract}
The purpose of this article is to develop an integrative model of small business growth that is both broad in scope and parsimonious in nature. Such a "big picture" model provides an opportunity (1) to gauge how much we really know about small business growth, when we simultaneously consider the constructs from the dominant perspectives, (2) to assess the contribution of each of these perspectives, (3) to examine the indirect effects that some constructs from one perspective might have on small business growth through constructs from another perspective, and (4) to consider different levels of analysis. Based on an analysis of data from 413 small businesses, we derive a set of propositions that suggest how entrepreneurial orientation, environmental characteristics, firm resources, and managers' personal attitudes directly and/or indirectly influence the growth of small businesses.
\end{abstract}

J. Wiklund

Jönköping International Business School, P.O. Box 1026, SE-551 11, Jönköping, Sweden

e-mail: johan.wiklund@jibs.hj.se

H. Patzelt

Entrepreneurship, Growth and Public Policy, Max Planck Institute of Economics, Kahlaische Strasse 10,

07745 Jena, Germany

D. A. Shepherd

Kelley School of Business, Indiana University, 1309

East Tenth Street, Bloomington, IN 47405-1701, USA

e-mail: Shepherd@Indiana.edu
Keywords Growth $\cdot$ SME $\cdot$ Entrepreneurial orientation · Attitude $\cdot$ Environment .

Resources

JEL Classifications L26

\section{Introduction}

Small firm growth is a research area that has attracted considerable attention in recent years. Despite substantial increase in research volume, recent reviews of the literature on small firm growth suggest that little is still known about the phenomenon, and conceptual development has been limited (see Davidsson and Wiklund 2000, for an extensive discussion of the reviews and shortcomings in the field). A major reason for these shortcomings, it is argued, is that this literature is highly fragmentedseveral theoretical perspectives have been developed, but there is little conversation between these perspectives. For example, a striking feature of reviews of studies of firm growth is that each study only covers a fraction of the variables considered important in other studies (Storey 1994; Wiklund 1998).

Most of the growth studies explicitly or implicitly relate to one of a number of theoretical perspectives to derive hypotheses for empirical testing. While this approach may contribute substantially to our in-depth understanding of aspects of small business growth, it is often left to the reviewer of this literature to 
attempt to bring together the pieces, in order to "see" the big picture. This is a difficult task, as evidenced by the lack of overarching models of growth (Davidsson and Wiklund 2000), yet important. In this article, we empirically combine five primary perspectives to develop a "big picture" model of small firm growth - a model that is integrative, and both broad in scope and parsimonious in nature. This requires a focus on theoretical constructs at a high level of abstraction taken from the theoretical perspectives in the field, simultaneously allowing the investigation of the structural relations of many endogenous variables.

There are a number of benefits arising from an integrative model. First, it helps us understand how previous research fits within a broader model of small business growth. Thus, it provides an opportunity to gauge how much we really know about small business growth when we simultaneously consider the constructs from the dominant perspectives. Second, we are able to investigate the relationship of constructs and small business growth, while controlling for possible redundancies. This provides the opportunity of better assessing the contribution of each perspective to our understanding of small business growth. Third, we not only investigate the relationships proposed within a perspective, but also relationships that only exist across perspectives, which further increases explanatory ability. That is, we examine the indirect effects that some constructs might have on small business growth, which have not been adequately considered to date. Fourth, to some extent, we consider different levels of analysis. We look at the individual (human capital and attitudes), the firm (resources, entrepreneurial orientation (EO), and growth), and the environment (industry, task environment, and changes of task environment). This creates some challenges, but opens up considerable opportunities for future research.

The article proceeds as follows. First, we introduce five dominant perspectives by exploring the major constructs of each, and their relationship with small business growth. Second, we describe the research method used to integrate the five perspectives to build an overall model of small business growth. Third, we build the model, and detail the results. Fourth, we discuss the results by proposing a number of relationships, and challenging scholars to empirically test them. Finally, we offer some concluding comments.

\section{Theoretical perspectives of small business growth}

Our purpose is to create an integrative "big picture" model of small business growth. In order to develop and test an integrative model, we start out by reviewing previous research. In doing so, we focus on three aspects of this literature. First, we identify the underlying theoretical perspectives. This term refers to conceptual assumptions made, which guides what is observed and included in theoretical models. Second, we examine the theoretical constructs that are salient within each of the theoretical perspectives. These constructs are theoretical aggregates of manifest variables studied. For example, human capital is a theoretical construct harboring manifest variables such as education or management experience. Therefore, we classify studies focusing on experience and education, as dealing with the theoretical construct human capital. Third, we causally link these theoretical constructs to each other and to growth. Given our purpose, it is not possible, nor is it necessary, to review all the relationships between the many endogenous variables provided within each of the perspectives, and their relationship with small business growth. Rather, the following review distills each perspective into its underlying constructs, and the relationship between those constructs and small business growth. Finally, we discuss potential conflicts between perspectives, and develop an integrative approach.

\subsection{Ontology of small businesses and identification of theoretical perspectives}

In order to identify important theoretical perspectives within the small business growth literature, it appears helpful to have a closer look at the ontology of small businesses, that is, the specification of their conceptualization (Gruber 1993). This is a difficult task, since small businesses, as all organizations, can undergo a variety of complex changes during their growth processes that make it difficult to determine the identity of the organization and observe organizational growth over time. For example, during their growth processes, small businesses can split up into more or less independent, separate legal units, and these units may not necessarily be contolled and owned by the same individuals to the same extent as the orginal 
entity did, yielding the question, which units should be considered when the growth of the original business is analyzed (Davidsson and Wiklund 2000). As Davidsson and Wiklund (2000) illustrate, different growth properties of the small business may be observed depending on whether a small business is viewed as all business activities controlled by an individual (group of individuals), as a particular business activity (set of business activities), or as a governance structure (coherently administered and controlled decision making unit). Moreover, research has emphasized that small businesses are part of complex networks of economic actors, and are dependent on the existence of other entities (Lewin and Regine 1999), which raises additional difficulties for defining their organizational boundaries. In order to cover this variety of possibilities to conceptualize a small business, Fuller and Moran (2001) advocated a complexity theory approach, and view small businesses as complex adaptive systems that can be understood to exist simultaneously at six hierarchical ontological layers, where each layer is an emergent property of the layer below.

As our purpose is to build an integrative model of business growth, the perspectives that we use as the basis of this model should — besides being prevalent in the literature-reflect the ontological layers introduced by Fuller and Moran (2001). The two fundamental layers of Fuller and Moran's model refer to the mental models and individual capabilities (bottom layer), and attitudes of small business owners. Our model relates to these two layers in that we include an attitude perspective (e.g., Bellu and Sherman 1995; Kolvereid and Bullvåg 1996; Miner et al. 1994) and a resourcebased perspective (e.g., Cooper et al. 1995; Davidsson and Honig 2003; Birley and Westhead 1990) including the human capital of the business owner as one important resource. The next higher ontological layer defines internal functional activities and relationships. The resource-based perspective covers this layer by refering to financial resources, which facilitate the development of internal functional activities, and network resources, including the relationship of the business owner to employees. The next higher ontological layer describes the business model (concept/ strategy/vision) of the small business, which we address by drawing on the EO (a strategic orientation, e.g., Wiklund 1999; Zahra 1991; Zahra and Covin 1995) and the strategic "fit" perspectives (e.g., Covin and Slevin 1989; Namen and Slevin 1993). Finally, the second highest and highest layer refer to the businessto-business relationships and external networks, respectively. Again, these are included in the network resources that are treated as part of the resource-based perspective in our model. Thus, the EO, strategic fit, resource-based, and attitude perspective are, consistent with Davidsson and Wiklund (2000), well-suited for building the basis to develop an integrated growth model since they reflect the different ontology of a small business, as identified by Fuller and Moran (2001). In addition, a prominent stream of the existing literature suggests that the environment, in which a small business operates, has a major impact on its growth opportunities (e.g., Kolvereid 1992; Pelham and Wilson 1996). We now introduce each perspective, and discuss the relationship between its constructs and small business growth.

\subsection{Perspective 1: entrepreneurial orientation and small business growth}

There is a longstanding tradition of attributing the growth of small businesses to their entrepreneurial activities (cf. Davidsson 1989a, b and his references). However, the exact association between the two has been unclear (Davidsson et al. 2002), largely because of definitional problems with the concept of entrepreneurial activities. Miller (1983) noted that firms and individuals can be entrepreneurial, and subsequent research has found that a small firm's degree of entrepreneurial activity, or EO, is linked to its growth and performance (e.g., Covin and Slevin 1989; Wiklund 1999). Miller summarizes the characteristics of an entrepreneurial firm as: "[O]ne that engages in product-market innovation, undertakes somewhat risky ventures, and is first to come up with 'proactive' innovations, beating competitors to the punch" (Miller 1983: 771). Based on this characterization, several researchers have agreed that EO is a relevant conceptualization of entrepreneurship in existing firms. EO refers to a firm's strategic orientation, capturing specific entrepreneurial aspects of decisionmaking styles, methods, and practices. As such, it reflects how a firm operates rather than what it does (Lumpkin and Dess 1996).

Entrepreneurial orientation involves a willingness to innovate in order to rejuvenate market offerings, 
take risks in order to try out new and uncertain products, services and markets, and to be more proactive than competitors toward new marketplace opportunities (e.g., Covin and Slevin 1989, 1990, 1991; Miller 1983; Namen and Slevin 1993; Wiklund 1999; Zahra and Covin 1995; Zahra 1993). Concerning the individual dimensions of EO, previous research suggests that each can have a universal positive influence on growth. Innovative companies, creating and introducing new products and technologies, can generate extraordinary economic performance (McGrath et al. 1996), and have even been seen as the engines of economic growth (Schumpeter 1934; Brown and Eisenhardt 1995). Proactive companies can create first-mover advantage, target premium market segments, charge high prices, and "skim" the market ahead of competitors (Zahra and Covin 1995). They can control the market by dominating distribution channels, and establish brand recognition. The link between risk taking and performance is less obvious. However, there is research to suggest that, while tried-and-true strategies may lead to high mean performance, risky strategies that lead to performance variationbecause some projects fail, while others succeedmay generate more growth in the long term (March 1991; McGrath 2001).

Furthermore, there is reason to believe that EO as an overarching construct can have universally positive performance implications. A general tendency in today's business environment is the shortening of product and business model life cycles (Hamel 2000). Consequently, the future profit streams from existing operations are uncertain, and businesses need to constantly seek out new opportunities. An EO can assist companies in such a process. Several empirical studies find support for EO's positive impact on performance (cf. Wiklund 1999; Zahra 1991; Zahra and Covin 1995), and that it is important for firms to sustain or enhance their EO over time to outperform competitors and experience high growth rates (Madsen 2007).

\subsection{Perspective 2: the environment and small business growth}

The environment provides the small firm with growth opportunities that can be exploited (Davidsson 1989a, b;
Stevenson and Jarillo 1986; 1990). For example, a number of studies assess the environmental influence of location, industry, and market on performance. Specifically, work by Audretsch and coauthors has shown that the degree of scale economies (see Audretsch 1995) and unionization of workers within an industry (Acs and Audretsch 1990), and the possiblity to introduce innovations (Vivarelli and Audretsch 1998) impact the growth of small businesses. Moreover, it is known that small business growth depends on the industry growth rate $\mathrm{Au}-$ dretsch and Mahmood 1994) and market maturity (Baldwin and Gellatly 2003). All these studies describe the objective environment of a firm, the hard facts, and implicitly assume that there are inherent performance advantages for small firms in particular industries, markets, or locations (Cooper et al. 1994). The environment is analyzed at an aggregate level, that is, the environment is assumed to have the same effect on all firms in a particular industry, market, or location.

However, research has found that small firms that grow, tend to develop profitable and expanding market niches (Storey 1996, 1997) that are often quite narrow and appear difficult to describe by objective, industry- or market-wide variables. To address this issue, researchers have suggested that it may be advantageous to decribe the environment of small businesses by a number of dimensions reflecting subjective perceptions of small business owners. These dimensions of the small firm's task environment have been investigated including the environment's munificence, turbulence, heterogeneity, hostility, dynamics, customer structure, and competition (Covin and Covin 1990; Kolvereid 1992; Pelham and Wilson 1996). First, dynamic environments are characterized by instability and continuous change. Windows of opportunity for growth arise from social, political, technological, and economic changes. Second, hostile environments create threats to the firm, either through increased rivalry or decreased demand for the firm's products, which can seriously reduce the growth opportunities for a small firm. Third, environmental heterogeneity captures the complexity of an environment, e.g., there maybe many different market segments with varied characteristics and needs to be served by those operating in that industry. In heterogeneous markets, it is relatively easier for small firms to find and 
develop specific market niches than in markets where demand is homogeneous.

\subsection{Perspective 3: strategic fit and small business growth}

Having identified the EO and environmental perspectives as important to explaining growth, it should be noted that the idea of EO being universally beneficial may be overly simplistic, as is the idea that an industry's attractiveness is universally beneficial for all firms. Scholars have long argued for the need for firms to achieve a fit between the characteristics of the firm and the environment in which it competes (Andrews 1987). It is likely that the effectiveness of any one strategic orientation depends on the nature of the environment. For example, one empirical study found that $\mathrm{EO}$ was associated with high performance among small firms operating in hostile environments, but not among those operating in benign environments (Covin and Slevin 1989).

Lumpkin and Dess (1996) suggest that the performance implications of EO are context specific, so that the relationship between EO and performance depends on the characteristics of the external environment. Therefore, increased understanding of the association between EO and growth is likely to be achieved by the concomitant consideration of strategic orientation and environment. Empirical research supports the proposition that the effect of EO on performance varies across different types of external environments (Covin and Slevin 1989; Namen and Slevin 1993).

\subsection{Perspective 4: resources and small business growth}

The resource perspective on small business growth harbors three distinct theoretical constructs. The first is related to the resource-based view in strategy, which has its focus on the resources of the firm. This perspective is focused on the combination and deployment of a firm's resources in order to achieve a competitive advantage (Conner 1991). The basic premise is that heterogeneous resources that are difficult to transfer or copy could be a source of sustainable competitive advantage. It has been suggested that resource-based theory can be important to understanding entrepreneurial phenomena (Alvarez and Busenitz 2001; Connor 1991), such as firm growth. The resource-based view, as defined in this literature, has started to be reflected in empirical entrepreneurship research (Alvarez and Busenitz 2001; Wiklund and Shepherd 2003a), and it has now been recognized that the link between the resources controlled by the firm and its effect on growth and performance is an important area for research.

One important extension of the resource-based view is the dynamic capabilities perspective (Teece et al. 1997). Dynamic capabilities refer to "the firm's processes that use resources-specifically the processes to integrate, reconfigure, gain and release resources - to match and even create market change" (Eisenhardt and Martin 2000: 1107). These processes are important for small firms to create, discover, and successfully exploit new opportunities (Zahra et al. 2006), and may, therefore, be a prerequisite for pursuing an EO strategy. For example, resourceintegrating capabilities with respect to selecting and combining risk-taking R\&D employees, and equip them with appropriate financial and physical resources (e.g., sophisticated devices) facilitate the innovative efforts of the small business, and thereby its EO. Since there is still debate in the literature about which general dynamic capabilities contribute to the discovery and exploitation of new opportunities (Davidsson 2004), we focus on the underlying resources.

Certain strands of resources have received particular attention in the small business growth literature. Small firms have limited access to financial capital, which limits their growth (e.g., Hartarska and Gonzalez-Vega 2006). Financial capital is the most general type of resource, and can be relatively easily converted into other types of resources, and access to more financial capital can help firms expand more and perform better (Bamford et al. 1997). Research on liquidity constraints posits that financial capital is essential for the activities necessary to achieve growth. Financial capital provides resource slack, allowing experimentation with new strategies and innovative projects that might not be possible in a more resource-constrained environment (Cyert and March 1963; Cooper et al. 1994), which increases the willingness to innovate and pursue new opportunities (Castrogiovianni 1996; Zahra 1991). 
A second construct in the resource oriented literature on growth relates to the human capital of entrepreneurs running their businesses (e.g., Cressy 2006; Koeller and Lechler 2006). The theory on human capital posits that individuals with more, or higher quality, human capital achieve higher performance in executing relevant tasks (Becker 1975). In the growth context, human capital refers to the knowledge, skills, and experience that assist in successfully growing the business. Human capital provides the entrepreneur with knowledge that assists them in identifying opportunities and knowledge of ways to more effectively and efficiently pursue growth opportunities (cf. Alvarez and Busenitz 2001). The human resources of a small firm reach beyond those of the entrepreneur-the total resources of the workforce are important factors in determining the overall resources of the firm (Chandler and Hanks 1994a, b; Birley and Westhead 1990).

The third construct associated with the resource perspective relates to network resources. Entrepreneurial networks can be divided into inter-organizational, intra-organizational, and inter-personal networks. First, inter-organizational networks denote the strategic alliances the small firm has with other organizations. For example, small firms can use alliances with universities (e.g., Powell et al. 1996; Zucker et al. 2002), other small firms (e.g., Higgins and Gulati 2006), or large corporations (e.g., Rothaermel and Deeds 2004; Lerner and Merges 1998) to acquire important knowledge (Zahra and Bogner 2000), financial capital (DeCarolin and Deeds 1999), and manufacturing and marketing capabilities (Audretsch and Feldman 2003). Several studies have confirmed the notion that interorganizational alliances can foster the growth of small businesses (e.g., Powell et al. 1996; Baum et al. 2000).

Second, intra-organizational networks can be understood as the relationships the small business owner has to other members of the management team. The nature of these relationships is crucial for the growth of young ventures because it determines team processes such as conflict and politics (Eisenhardt and Bourgeois 1988; Eisenhardt and Schoonhoven 1990) that can be detrimental to the growth of small businesses (Ensley et al. 2002). An important prerequisite to counteract these processes is that the intraorganizational networks are characterized by high levels of cohesion, shared leadership, and a common vision of the management team, which facilitate the development of small firms (Ensley et al. 2003). Existing literature suggests that shared team-specific experience can support these processes, thereby leading to higher growth rates (Kor 2003).

Third, interpersonal networks refer to interpersonal relationships of the small business owner, which form the basis of her/his social capital (Granovetter 1985; Brüderl and Preisendörfer 1998; Bosna et al. 2004). Social capital is particularly important for accessing, and reducing the costs of, resources (Cromie et al. 1994), such as those necessary to achieve growth. For example, social capital can enhance an individual's access to information about new opportunities and the equipment, financial capital, advice, information, and reassurance necessary to exploit such growth opportunities (Birley 1985; Johannisson 2000).

\subsection{Perspective 5: growth attitude and small business growth}

In most economic literature, growth attitude is taken for granted-people act in ways to maximize their profits. Psychologists, concerned with all aspects of human behavior, have a more diverse view of the motives and attitudes underlying economic behavior. In the small business context, this diverse view may be of particular importance. In the entrepreneurship literature, Sexton and Bowman-Upton (1991) criticize growth models that do not consider the role of small business managers' attitudes, and argue that the growth attidutes of small business managers set limits to the growth a business will achieve. We know that people start and operate their own firms for a variety of reasons other than maximizing economic returns (Davidsson 1989a, b; Delmar 1996; Kolvereid 1992; Roper 1999; Storey 1994).

The causal direction between growth attitude and growth has been questioned. Growth may be an "acquired taste," as suggested by some authors (e.g., Davidsson et al. 2002). That is, small business managers who successfully manage their firms through a growth process (independent of their own previous attitude) may become and build up a more positive growth attitude as a result of the successful completion of growth. However, studies of growth using appropriate longitudinal designs have found 
support for a positive effect of attitude on growth (e.g., Bellu and Sherman 1995; Kolvereid and Bullvåg 1996; Miner et al. 1994; Wiklund and Shepherd 2003b).

The fulfillment of noneconomic personal goals, such as gaining independence or developing ideas, are stated as primary reasons for operating one's own firm (Douglas and Shepherd 2000). Whether or not running a small firm actually leads to the fulfillment of personal goals is an open question. It depends on whether there is a strong link between other aspects of attitude and the small business manager's goals to grow the business. For example, not all small business managers have, as a goal, to grow their business (Wiklund et al. 2003). Growth implies radical changes to the characteristics of the business. These changes may run counter to the founder's initial goals of, for instance, personal independence. Indeed, previous research indicates that expectations of changed working conditions arising from business growth are a primary concern for small business managers, which, in turn, affects their attitudes toward expanding their businesses (Wiklund et al. 2003). For example, as the business grows, the tasks required of the small business manager will likely also change. If the small business manager is favorably disposed to performing the new tasks that firm growth requires, then s/he will likely have a more positive attitude toward growth (holding the other factors of growth constant).

\subsection{Conflicting views and integration of the perspectives}

Above we have identified five theoretical approaches and their accompanying theoretical constructs that are prevalent in the existing literature to explain small business growth. It is important to note, however, that these perspectives are not necessarily independent of each other, and that they may lead to conflicting hypotheses about growth under certain circumstances.

In the resource-based perspective, for example, the environment provides few restrictions to the growth of the small business. Although the expansion for particular resources, and products may be limited by increasing resource costs and declining revenues for individual products, the firm can use other resources and create new markets in order to grow. As long as the managers are able to manage and deploy the resources available (Grant 1991), the environment does not limit the firm to a fixed set of growth opportunities. The firm can always grow to the extent that it has the resources to identify and exploit growth opportunities. In contrast, the environmental perspective states that growth opportunities are provided by the context, in which the firm operates, and that the small business can only grow when it exploits the opportunities offered by the environment (Davidsson 1989a, b; Stevenson and Jarillo 1986, 1990).

Moreover, there may exist interdependencies between the environment of the small business and the growth attitudes of the business owner, since the nature of the growth opportunities offered by the environment specifies the tasks the business owner has to perform to achieve growth. Since individuals favor different work tasks (Miner 1990; Delmar 1996), the growth attitude of business owners may be determined, in part, by the environmental conditions, in which small businesses operate.

One way to partially resolve the above issues and integrate the perspectives is to view the strategic orientation-here, the EO- of the small business as a central construct mediating the impact of resources, environment, and attitude on growth. For example, the availability of resources has been described as a prerequisite to engage in experimentation, risktaking, and innovation (March 1991), and is, therefore, necessary for small businesses to develop an EO (Miller 1983; Covin and Slevin 1989; 1990). Moreover, it is known that firms are more likely to develop an EO under certain environmental conditions, specifically in dynamic and hostile environments (Miller 1983). Finally, scholars have highlighted the central role of the leader's attitude for strategic choices of firms (Kets de Vries et al. 1993). Thus, EO may serve as a central construct that partially takes into account and integrates conflicting and complementary implications that individual theoretical perspectives have on small business growth.

Even though EO may mediate the effect of resources, environment, and attitutde on growth, however, it is likely that the EO-growth relationship itself is dependent on these constructs, specifically the environment of the small business. This is highlighted by the strategic fit perspective, which states that the strategic posture of the firm must match environmental conditions. Indeed, research has 
shown that EO does not have a uniformly positive effect on growth, but that under certain conditions, there may even be a "dark side" of EO. For example, it appears that an EO can be inferior to a more conservative strategic orientation, and even detrimenal to growth under benign environmental conditions because in the latter case risky, innovative, and resource-consuming endevors are unnecessary to achive high performance (Covin and Slevin 1989).

\section{Building an integrated model of small business growth}

\subsection{Analytical approach}

The next task of our analysis is to develop an empirical model that links the theoretical perspectives to growth and to each other in order to reflect the relationships that we have discussed above. In doing so empirically, we need an analytical approach that allows measurement of theoretical constructs consisting of a number of individually measured indicators (such as EO or attitude, see below), the possibility to include multiple links between these constructs in the model, and the potential to revise the model in light of empirical findings. That is, our first goal is to analyze the direct effect of EO on growth, and the effect of resources, environment, and attitude on EO. In a second step, we aim to relax the boundary conditions of this model by allowing for additional direct effects of resources, environment, and attitude on growth. Comparing the quality (explained variance) of both models allows us to assess the importance of individual relationships. To realize this two-step approach empirically, we rely on partial least square (PLS) analysis. Central to PLS is that theoretical constructs are incorporated directly in the model as latent variables consisting of a number of manifest indicators. For example, this allows us to include constructs such as EO and attitude that are measured by 8 and 14 individual indicators, respectively (see below). The analysis then reveals structural relationships between the constructs. Therefore, PLS is a suitable analytical approach for our study. PLS has been used in management research (Hulland 1999), in particular, for explaining complex relationships (Fornell and Bookstein 1982), such as those for explaining growth.

\subsection{Sample and design}

The sampling frame was taken from the CD-ROM database UC-Select, which includes all incorporated Swedish companies. We randomly sampled independent firms from four sectors-knowledge intensive manufacturing, laborintensive manufacturing, professional services, and retail. A total of 808 small business managers from the sampling frame were contacted, of which 465 first responded to a telephone interview, and then to a mail questionnaire. Half of the sample had between 10 and 19 employees, and half between 20 and 49 employees, as stated in their latest annual report. These business sizes correspond to the European Union definition of a small business. We believe that this definition of a small business makes sense for our study, which takes place in a European setting, however, it is important to note that other studies, particularly those in non-European countries, have chosen other definitions. This may limit the comparability of our results to these other studies.

Data were collected on the independent and control variables. One year later, these 465 small business managers were again asked to complete a telephone interview, this time concerning only the dependent variable. Eighteen failed to do so, of which five had gone out of business, and 34 managing directors had been replaced during the period and were therefore, excluded from the analyses. The final sample, therefore, consists of 413 small business managers (overall response rate of $51 \%$ ).

\subsection{Variables and measures}

The theoretical constructs in the model are based on the review of literatures above. The large number of low level variables in previous research can be abstracted into a small number of theoretical constructs-EO, environment, resources, and attitudeand the resulting model is illustrated in Fig. 1.

\subsubsection{Small business growth}

There is little agreement in the existing literature on how to measure growth, and scholars have used a variety of different measures. These measures include, for example, growth of sales, employees, 
Fig. 1 Diagram of the results for the revised model of small business growth Note: Only relationships with path coefficients above or equal 0.10 are depicted as arrows

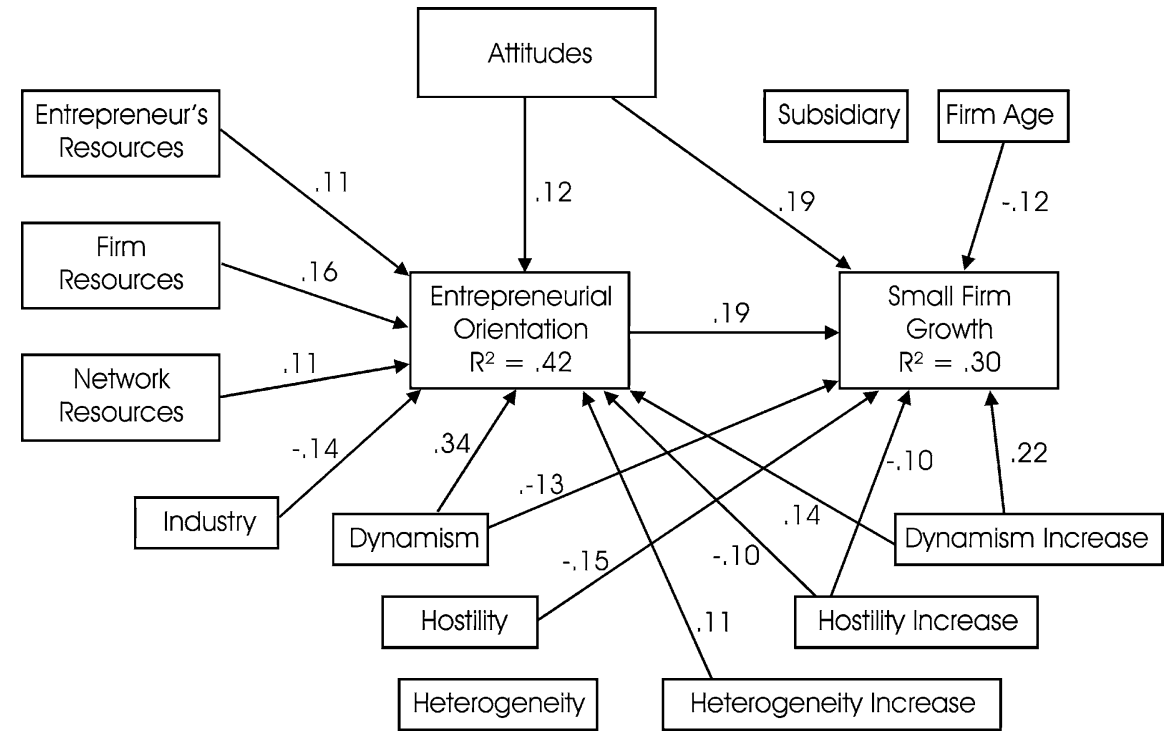

\subsubsection{Entrepreneurial orientation}

assets, profit, equity, and others (for a discussion see Davidsson and Wiklund 2000; Weinzimmer et al. 1998). Moreover, the time span, over which growth is analyzed in the literature, varies considerably, and ranges from one to several years. Also, growth has been measured in absolute or relative terms. Although it is not the purpose of this study to provide an analysis of different growth measures and their comparability, we point out that the different aspects embedded in each of the measures and combinations thereof may limit the comparability of our results to other studies and their generalizability.

To ensure some comparability with a maximum amount of existing growth studies, we decided to use four measures to capture small business growth. These measures capture the two most often used indicators (sales and employee growth). Moreover, it has been claimed that multiple growth indicators give richer information, and thus, are better than single indicators (Birley and Westhead 1990; Weinzimmer et al. 1998). Growth in terms of sales and employment was calculated as the relative change in size from 1996 to 1999 in all businesses controlled by the respondent. When assessing performance, comparisons with competing businesses in the market reveal important additional information (Birley and Westhead 1994). Therefore, respondents were asked to rate their sales and employment growth compared to competitors on five-point scales. Each of the variables were standardized, and summed to an index. The Cronbach's Alpha value of the scale was .91.
Miller's (1983) original scale for EO consisting of eight items was used. Two of these items describe the risktaking behavior, three describe the proactiveness, and three refer to the innovativeness of the firm. A large number of studies have used this scale (e.g., Zahra and Covin 1995) or modifications thereof (e.g., Covin and Slevin 1989, 1990) to measure EO. Later, Lumpkin and Dess (1996) conceptually introduced autonomy and competitive agressiveness as potential additional components of the EO construct, however, even in recent EO studies scholars have decided to use the wellvalidated scale of Miller (e.g., Wiklund and Shepherd 2005). We follow these studies and refer to the original 8 -item scale with risk-taking, proactiveness, and innovativeness as its underlying dimensions.

The items of Miller's (1983) EO scale are of the forced choice type, with pairs of opposite statements. A seven-point scale divides the two statements. In order to avoid response set contamination, the questions were arranged so that the entrepreneurial and nonentrepreneurial statements appeared on both the right and left sides. The theoretical construct is reflected in the indicators, i.e., each indicator brings unique information to the construct (cf. Fornell et al. 1990).

\subsubsection{Environment}

A total of six dimensions of the task environment are included. The scales for measuring environmental 
dynamism, heterogeneity, and hostility were taken from Miller and Friesen (1982). Changes over the past three years along these three environmental dimensions have their origin in Miller (1987). All items were measured on seven-point opposite statement scales. Each dimension consists of a number of items to reduce the complexity of the overall model. Association with one of four broad industry categories was taken from the data register. Specific questions were also asked about other industry characteristics, i.e., customer concentration, supplier concentration, and exports. The theoretical construct of industry is formed by these indicators.

\subsubsection{Resources}

All theoretical constructs pertaining to resources are formative, i.e., each indicator provides a unique aspect of resources. Resources of the firm consists of size in terms of employees sales, management team size, number of employees having university degrees, board size, and investment by external owner. In order to capture a relative measure of size and financial slack, we asked respondents to compare the firm's size and capital availability to that of its competitors. Miller's (1987) items were used to operationalize the perceived use of employees and the board in the decision making process. The human capital of the manager was operationalized by various measures of experience and knowledge. Indicators included the type and length of education and training, experience with managing different types of firms (i.e., management, same industry, rapidgrowth firm, and maximum number of subordinates), and tenure in present position. We also collected information on age, ethnicity, and gender, as well as whether the respondent started, inherited, bought, or is employed by the firm. These measures used to operationalize human capital are taken from Davidsson $(1989 a, b)$. In order to operationalize social capital, we asked respondents how important was a particular contact in providing advice on important decisions from a list of nine types of contacts (Davidsson 1989a, b, and one original item). These nine items were factor analyzed resulting in three factors, and corresponding indices were constructed. Respondents also indicated the firm's number of external board members.

\subsubsection{Attitude}

The work-task of managing a small business is likely to involve taking moderate risks, assuming personal responsibility for performance, paying close attention to feedback in terms of costs and profits, and finding new or innovative ways to make a new product, or provide a new service (e.g., Miner 1990; Miner et al. 1994). Since individual motivation consists of several related constructs that affect behavior (see Locke (1991) for a review), we relied on a number of concepts associated with the small business manager work-tasks. The different motives are viewed as attitude objects, and the strengths of the motives are tapped by the respondent's attitude toward the object. We build on the tripartite view, according to which attitudes can be broken down into three different classes of evaluative responses (Eagly and Chaiken 1993): (1) cognitive responses, also known as beliefs, are thoughts that people have about the attitude object; (2) affective responses consist of feelings, moods, or emotions that people have in relation to the attitude object; and (3) behavioral responses are the overt actions or intentions exhibited by people in relation to the attitude object. The goals of the respondent are viewed as affective responses, since they have to do with their feelings regarding a number of possible goals ( 8 items original, 10 from Davidsson 1989a, b). These 18 items were factor analyzed, resulting in six factors, and corresponding indices were constructed. Favored work-tasks are also seen as affective responses for the same reason (15 items from Delmar 1996). These items were factor analyzed resulting in four factors and corresponding indices were constructed. Expectations of changes that will occur in the firm as a result of growth refer to the beliefs held by respondents. Thus, expected consequences of growth are classified as cognitive responses ( 2 items original, 8 from Davidsson 1989a, b). These items were factor analyzed resulting in two factors and corresponding indices were constructed. The final set of variables concern growth intentions over the next 5 years. These variables are viewed as behavioral responses and were calculated based on present size and ideal size 5 years into the future in terms of employment and sales (2 items from Davidsson 1989a, b). This leads to a total of 14 variables. The theoretical construct of attitude is formed by these 14 variables, i.e., each variable brings some unique information to the construct (cf. Fornell et al. 1990). 


\subsection{Analysis}

One of the important aspects of the research presented here is how the theoretical constructs utilized under different theoretical perspectives are linked to each other. In order to empirically assess this, there are two steps to the analysis. The first step tests the explanatory ability of a parsimonious integrated model. In this model, limited assumptions are made concerning structural relationships between constructs. Step two utilizes the information provided by the first step to revise the model in an attempt to increase its explanatory ability. One feature of PLS analysis is that it computes the correlation between all constructs, which can be used as a cue for adding structural relationships in the model. The model is generated by predicting EO and small business growth simultaneously. The simultaneous exploration of these relationships provides a big picture model of small business growth and allows for a series of propositions for empirical testing by future research.

\subsubsection{Step 1: predicting growth by using the full integrative model}

In the parsimonious base model, there are two endogenous constructs: EO and growth. That is, the model includes the direct effect of EO on small business growth, the direct effects of resources, attitude, and environment on EO, and the indirect effect of resources, attitude, and environment on small business growth via their impact on EO. The logic behind this base model builds on the basic premises of human action theory (Greve 2001). It suggests that, while characteristics of the small business or its manager may effect growth, such characteristics only have an indirect effect. They must be transformed into some type of action and activity in order to effect growth. Merely having the goal of expanding the business does not create growth unless the appropriate actions are taken. EO is a variable that captures actions and activities. Therefore, the base model assumes that all other constructs have an effect on EO, while EO, in turn, is the only construct affecting growth. The main focus of this first step of the analysis is, therefore, to: (1) test the ability of the theoretical constructs in the model to predict growth, (2) test the ability of the theoretical constructs in the model to explain EO in a growth context, i.e., given that growth is the ultimate dependent variable: to what extent can the model explain EO? (3) determine the relative importance of different theoretical constructs in the explanation of growth and EO, and (4) detect relationships among theoretical constructs not previously anticipated, which could lead to model revisions.

Table 1 shows the results of the analysis. The explained variance of growth is $13 \%$. Approximately $42 \%$ of EO is explained in the model, which implies that the environment (industry and task), resources, and attitude $d o$ provide an explanation, in part, of variance in EO, even when the ultimate dependent variable is small business growth. The magnitude of the path coefficient for each latent construct, when predicting EO, provides information on the relative importance of each construct, i.e., the greater the magnitude of the path coefficient, the greater the importance of that construct in predicting EO. The task environment stands out as the single most important correlate of EO, whereas the magnitudes of the other path coefficients are fairly similar. All path coefficients reach .10 or above (Falk and Miller 1992 suggest .10 as a suitable cutoff for when a path coefficient should be considered), which suggests that all constructs in the model make a contribution to the explanation of the EO.

Table 1 PLS results for the base model of EO on small business growth

\begin{tabular}{llc}
\hline Predictor construct & $\begin{array}{l}\text { Predicted } \\
\text { construct }\end{array}$ & $\begin{array}{l}\text { Path } \\
\text { coefficient }\end{array}$ \\
\hline Attitudes & EO & .13 \\
Industry & EO & -.13 \\
Task environment & EO & .44 \\
Entrepreneur's resources & EO & .10 \\
Firm resources & EO & .16 \\
Network resources & EO & .10 \\
Firm age & Growth & -.16 \\
Subsidiary & Growth & .08 \\
Entrepreneurial orientation & Growth & .29 \\
Explained variance and model fit & & \\
$\mathrm{R}^{2}$ EO & .42 & \\
$\mathrm{R}^{2}$ Growth & .13 & \\
RMS Cov (E, U) & .06 & \\
\hline
\end{tabular}

Note: Path coefficients are equal to standardized regression coefficients in multiple linear regression analysis. RMS Cov $(\mathrm{E}, \mathrm{U})$ measures model fit. The closer to zero, the better the model fits the data 


\subsubsection{Step 2: revising the model for predicting growth}

The full model tested in step 1 above explained only $13 \%$ of the variance in growth. This relatively low level of explained variance could indicate that the model is mis-specified to some extent. Given the purpose of this article, we use PLS in an interactive fashion so that we can "build" an integrative model of small business growth. An assessment of the correlations among latent variables suggests some additional direct linkages from these constructs to growth. More precisely, it appears that aspects of the task environment and attitude have direct effects on growth.

Adding these direct effects, we find that explained variance increases substantially to $30 \%$. This increase in explained variance indicates a substantial model improvement. The total explained variance in growth is consistent with, or greater than, many models of small business growth (see Delmar (1997)) for a review of explained variance in growth models). The graphical representation of the model is displayed in Fig. 1, and the results in Table 2. Due to space limitations, the regression weights and factor loadings for manifest indicators are reported in the Appendix. As could be anticipated, explained variance in EO decreases somewhat (from 0.42 to 0.41 ) in this revised model. However, $30 \%$ of the growth variable and, on average, $36 \%$ of the variance in the two endogenous variables is explained, which is a major model improvement (Explained variance is the best estimation of model fit in PLS analysis, and goodness-of-fit indices are largely irrelevant (Hulland 1999)).

In sum, the model demonstrates that attitude and components of the task environment (dynamism, hostility, and dynamism increase) have a direct effect on small business growth. Components of resources (resources of the individual, network resources, and resources of the firm), attitude, industry, and components of the task environment (dynamism, dynamism increase, hostility increase, heterogeneity increase) have an indirect effect on small business growth through EO. Most path coefficients are larger in relation to EO than to small business growth (exceptions are attitude, increase in environmental dynamism, and environmental hostility). This highlights the importance of understanding the antecedents of EO, offers a solid basis for an exploration of the indirect effect of constructs on small business growth via EO, and, although EO
Table 2 PLS results for the revised model of small business growth

\begin{tabular}{|c|c|c|}
\hline Predictor construct & $\begin{array}{l}\text { Predicted } \\
\text { construct }\end{array}$ & $\begin{array}{l}\text { Path } \\
\text { coefficient }\end{array}$ \\
\hline Attitudes & $\mathrm{EO}$ & .12 \\
\hline Industry & $\mathrm{EO}$ & -.14 \\
\hline Dynamism & $\mathrm{EO}$ & .34 \\
\hline Heterogeneity & $\mathrm{EO}$ & .07 \\
\hline Hostility & $\mathrm{EO}$ & -.07 \\
\hline Dynamism increase & $\mathrm{EO}$ & .14 \\
\hline Heterogeneity increase & $\mathrm{EO}$ & .11 \\
\hline Hostility increase & $\mathrm{EO}$ & -.10 \\
\hline Entrepreneur's resources & $\mathrm{EO}$ & .11 \\
\hline Firm resources & $\mathrm{EO}$ & .16 \\
\hline Network resources & $\mathrm{EO}$ & .11 \\
\hline Firm age & Growth & -.12 \\
\hline Subsidiary & Growth & -.01 \\
\hline Attitudes & Growth & .19 \\
\hline Dynamism & Growth & -.13 \\
\hline Hostility & Growth & -.15 \\
\hline Dynamism increase & Growth & .22 \\
\hline Heterogeneity increase & Growth & .07 \\
\hline Hostility increase & Growth & -.10 \\
\hline Entrepreneurial orientation & Growth & .19 \\
\hline \multicolumn{3}{|c|}{ Explained variance and model fit } \\
\hline $\mathrm{R}^{2} \mathrm{EO}$ & .41 & \\
\hline $\mathrm{R}^{2}$ Growth & .30 & \\
\hline RMS Cov (E, U) & .06 & \\
\hline
\end{tabular}

Note: Path coefficients are equal to standardized regression coefficients in multiple linear regression analysis. RMS Cov $(\mathrm{E}, \mathrm{U})$ measures model fit. The closer to zero, the better the model fits the data.

explains an important amount of the variance in small business growth, there is still a need to explore the direct effect of other constructs on growth.

\section{Propositions}

Next, we explore each perspective on growth in terms of the relationship between its relevant constructs and small business growth, while controlling for the impact of the major constructs from other perspectives. The results are specified in terms of propositions regarding the direct and indirect effects of these constructs on small business growth through EO. When we find that a construct does not provide a significant explanation of 
the variance in the dependent construct, we propose that the relationship does not exist in order to provide a challenge for subsequent research to refute the proposed nonrelationship. We will discuss our propositions in light of existing small business literature. However, we would like to emphasize again that not all studies referred to below draw on the same definition of small business and the same operationalization of growth, as we do. Nevertheless, we believe that comparison with these studies does provide some support for the propositions.

\subsection{Entrepreneurial orientation and small business growth}

Proposition 1 Entrepreneurial Orientation has a positive effect on small business growth.

Proposition 1 suggests that strategy of a small business with respect to EO affects its growth to a substantial degree, even when other factors are taken into account. It is sometimes argued that small firms are subjected to strong environmental pressures forming their development and performance (Aldrich and Auster 1986). From an ecological or institutional standpoint, the future growth of the small firm is largely a function of previous growth due to inertia and path dependence. Once the firm has been launched in a particular environment, managers can do little to affect the future of the firm due to environmental pressures and internal inertia. Ecological research claims that the findings the researchers have reached about the influence of purposeful action on firm outcomes, can be largely attributed to methodological artifacts (Carroll and Hannan 2000). On the contrary, in our research, we find that the strategic choices made by management in developing an EO of their firm have a strong independent influence on growth. These results are consistent with a recent study by Madsen (2007), showing that SMEs maintaining or even increasing their EO over time experience a faster employment growth than SMEs with decreasing EO.

\subsection{Environment, strategic "Fit," and small business growth}

Proposition 2 The current task environment has a direct effect on small business growth, and has an indirect effect on small business growth through EO. Specifically, (a) dynamism has a direct negative effect, and an indirect positive effect, on growth, (b) hostility has only a direct negative effect on growth, and (c) heterogeneity has neither a direct nor indirect effect on growth.

In general, proposition 2 suggests that the different dimensions of the task environment construct have differential direct and indirect impacts on small business growth. Specifically, proposition 2a suggests that dynamism simultaneously has a positive and a negative impact on small business growth. Dynamism has a direct negative impact on small business growth, which suggests that firms in dynamic environments grow slower than those in more stable environments, if their levels of EO are held constant. However, the indirect positive effect of dynamism on growth through EO suggests that in dynamic environments, where market demand is constantly shifting, opportunities become abundant, and growth should be highest for those firms that have an orientation for pursuing new opportunities because they have a good fit between their strategic orientation and the environment. Firms more content with existing operations, however, are less likely to benefit from a dynamic environment, because market demand might shift away from the firm's products negatively impacting growth.

Other empirical observations support this notion. Zahra (1993) found a strong positive relationship between EO and performance among firms in dynamic growth environments, whereas these relationships were largely negative among the firms present in static and impoverished environments. Similarly, Miller (1988) found that innovative strategies in uncertain (unpredictable and dynamic) environments were associated with higher performance.

Proposition $2 \mathrm{~b}$ suggests that hostility has only a direct negative effect on small business growth, and no direct effect on growth through EO. Such a finding is consistent with, for example, deterministic perspectives of the environment and firm performance where the environment is all powerful, and there is little that the small business can do to recognize the hostility of the environment and change the firm's growth trajectory by changing its strategic orientation (e.g., Aldrich and Auster 1986). It is also consistent 
with the empirical finding that during recessions, when the environment is generally hostile, small firms are more likely than large firms to go out of business.

Proposition $2 \mathrm{c}$ suggests that heterogeneity has no direct or indirect effect on small business growth. It could be that this task environmental variable does not increase our understanding of firm growth, or it may be useful for explaining large firm growth, but for small businesses, it has no effect on growth, or, of course, there is an effect (direct and/or indirect), but we are unable to detect the relationship. Whether heterogeneity does, in fact, impact small business growth requires more empirical tests. It will be interesting if others can refute our proposition.

Proposition 3 The change in the task environment has a direct effect on small business growth and has an indirect effect on small business growth through EO. Specifically, (a) dynamism increase has a direct positive and an indirect positive effect on small business growth, (b) hostility increase has a direct negative and an indirect negative effect on growth, and (c) heterogeneity increase has only an indirect positive effect on growth.

Proposition 3a suggests that dynamism increase has both a direct positive and an indirect positive effect on small business growth. That is, as the environment is perceived to be increasing in dynamism, then this not only directly provides growth opportunities for small businesses, but also encourages these businesses to undertake more EO in order to more effectively discover and exploit these opportunities for growth. It is interesting to compare the implications of propositions $2 \mathrm{a}$ and $3 \mathrm{a}$. The direct negative effect of dynamism, in combination with the direct positive effect of dynamism increase, suggests an important difference between an assessment of the snapshot image of the environment and environmental changes over time. Our interpretation of this finding is that small businesses have the ability to move between different types of task environments. Once they find a profitable market niche, it is important that this opportunity is exploited before moving on to pursue other opportunities.

Proposition $3 \mathrm{~b}$ suggests that a hostility increase has a direct and indirect negative effect on small business growth. As a small business environment becomes more hostile, small businesses are likely to become less entrepreneurial in their orientation, and the environment is likely to provide fewer resources and opportunities to grow the business.

Proposition $3 \mathrm{c}$ suggests that heterogeneity increase has a positive indirect, but no direct effect on small business growth. This means that an increase in the complexity of the environment encourages the small businesses to develop a more EO, possibly to find or create attractive niches arising from the additional heterogeneity. It might also be that the small business is able to grow with less threat of retaliation, given the increasing complexity in the environment (e.g., greater causal ambiguity (Rumelt 1987)).

Proposition 4 Industry has a direct effect on small business growth, but does not have an indirect effect on small business growth through EO.

Covin and Slevin (1991) suggest that industry technological sophistication and industry life cycle stage affect EO, e.g., a disproportionately high share of hi-tech firms have been found to be entrepreneurial due to environmental conditions (Covin and Slevin 1991). However, to the authors' knowledge, these relationships have not yet been empirically tested. Zahra (1993) proposes a rationale for not testing these relationships because technological sophistication and industry lifecycle stage refer to one type of conceptualization of the environment, whereas environmental dynamism, heterogeneity, and hostility refer to another. Therefore, according to Zahra, the researcher should choose only one of the conceptualizations, since the other becomes redundant.

Proposition 4 suggests that industry has an effect on small business growth, but no indirect effect, whereas propositions 2 and 3 suggest that the task environment and changes in that environment have both a direct and an indirect effect on small business growth through EO. This suggests that a possible explanation for the lack of research on the relationship between industry and EO in explaining small business growth is that there is no relationship (or it is a difficult one to find), and research presenting nonfindings is less likely to be published. It also has implications for Zahra's rationale that to include both industry and task environment variables in a single model is redundant; our proposition suggests that the impact of industry and task environment variables differ in their relationship with small business growth. Relative to including task environmental variables in a model, using only 
industry variables would overlook the direct effects of the environment and understate the importance of the indirect influence of the environment on small business growth though EO.

In sum, rather than a perspective of reductionism targeted at the environmental variables, our propositions suggest that it is likely important to include measures of change in the task environment over and above simply using measures of the current task environment. It also appears important to investigate the direct and the indirect effects (through EO) of the environment on small business growth, at least the indirect effects of dynamism, dynamism increase, hostility increase, and heterogeneity increase. We also propose that the redundancy created by including both industry variables and task environment variables may be less than first expected, and including both the "industry" and "task environment" constructs might improve the explanatory ability of small business growth models.

\subsection{Resources and small business growth}

Proposition 5 Resources have an indirect positive effect on small business growth through EO, but do not have a direct effect on small business growth. Specifically, (a) the resources of the firm (financial and human) have only an indirect positive effect on growth (b) human capital of the manager has only an indirect positive effect on growth, and (c) the manager's social network has only an indirect positive effect on growth.

In proposition 5a, we suggest that firms with greater access to human and financial resources are more likely to undertake an EO, which, in turn, facilitates small business growth. Studies have found that access to more financial capital facilitates the pursuit of resource-intensive growth strategies (Cooper et al. 1994) because, it is argued, that slack resources can be used for experimentation with new strategies and practices, allowing the business to pursue new growth opportunities (Penrose 1959). Our proposition is consistent with these findings in that financial capital encourages a change to a more EO, which in turn leads to higher growth.

In proposition $5 \mathrm{~b}$, we propose that managers with considerable human capital know where to look for opportunities (Shane 2000), can more accurately assess the value of potential opportunities (Venkataraman 1997), and have the ability to exploit these opportunities (Cressy 2006; Kim et al. 2006), which encourages an EO. It is this EO that then facilitates small business growth. We suggest that human capital has little to no direct influence on small business growth - such as producing higher quality decisions that have a positive influence on growthrather, we propose, human capital has a positive impact on EO, which, in turn, has a positive impact on growth.

In proposition $5 \mathrm{c}$, we address the manager's social network. Research on social capital suggests that network ties provide access to resources necessary for opportunity exploitation (Birley 1985; Johannisson 2000). We propose that these resources are important to achieve small business growth, but primarily because they encourage an EO, and it is the EO that drives the small business growth. Propositions $5 \mathrm{~b}$ and $5 \mathrm{c}$ both suggest that sources of resources that have an indirect positive effect on small business growth extend beyond the organization, and reside in the small business manager (human capital) and the network of the small business manager, and are consistent with those advocating the importance of investigating the resources of the individual in entrepreneurship research (Alvarez and Busenitz 2001).

The implications for future research arising from proposition 5 is that when investigating the role of resources on small business growth, EO should be considered. EO could be controlled to refute our proposition that resources do not have a direct effect on small business growth. Alternatively, EO could be included in the model to test the nature of the indirect relationship that resources have with small business growth through EO. Our findings suggest that in a small firm, resources must be put to use in creative ways (i.e., through adopting an EO). Merely providing a small firm with more money does not automatically mean it will expand.

\subsection{Attitude and small business growth}

Proposition 6 The growth attitude of the manager has a direct positive effect on small business growth and has an indirect positive effect on small business growth through EO. 
There have been a few studies that have researched the link between attitude and small firm growth, and have found that attitude may provide an important explanation, at least in part, for why some firms grow, while others do not (cf. Kolvereid and Bullvåg 1996; Miner 1990; Miner et al. 1989; Wiklund and Shepherd 2003b). Our model further delineates this explanation by proposing that the relationship between attitude and growth is two-fold: (1) a direct relationship between growth attitude and growth and, (2) an indirect relationship where growth attitude encourages a more entrepreneurial strategic orientation, which, in turn positively impacts small business growth.

The direct relationship is consistent with motivation theories that posit that, those who are more motivated (have a more positive attitude toward growth) will perform better at a task (in this case growth) when they invest more time and energy into that task (e.g., Davidsson 1989a, b; Kolvereid 1992; Miner et al. 1989). Furthermore, we anticipate that certain attitudinal patterns of the small business manager, in terms of goals, work tasks, growth aspirations, and expected consequences of growth can be expected to generate a more EO and thus, choose a strategy facilitating growth.

The goals of the small business manager are likely to influence the firm's strategic orientation. It appears that the personal goals of the entrepreneur have an influence on the strategy of the firm, mediated through the decision to behave entrepreneurially (Naffziger et al. 1994). For example, those individuals who have goals to be creative are more likely to be innovative and strive to develop new products (Amabile 1988), which is anticipated to have a positive influence on EO (see Khan (1986), who found that creativity was the most important variable in determining new venture success).

The small business manager's favored work tasks are also likely to influence the firm's EO. Miner (1990) found that high growth entrepreneurs scored higher on the motivational construct of "a desire to think about the future and anticipate future possibilities" than did other entrepreneurs. An interest in developing strategies for the future and working in marketing appears to be related to growth, while those who favor work tasks associated with operations and accounting appear to operate small businesses that experience less growth.
Finally, the small business manager's expected consequences of growth are likely to influence the firm's EO. Peoples' images of the future influence their current decisions by determining their goals and the procedures they select for achieving them. A connection between the present and the future is typically forged by people imagining various futures, considering the advantages and disadvantages of each, selecting their preferred end states, and then developing plans to achieve their desired goals, while avoiding negative outcomes (Locke and Latham 1990). Therefore, managers' images of the future outcomes arising from growth likely influence their strategic orientation.

\section{Discussion and limitations}

In this article, we set out to develop a broad integrative model of small firm growth building on the theoretical perspectives utilized in previous research. Our model also gave us the opportunity to evaluate the relative importance of different perspectives and constructs.

One particularly interesting finding is that resources only had indirect effects on growth. That is, the effects were fully mediated by the EO construct. This finding is consistent with the spirit of the resource based view of strategy. Eisenhardt and Martin (2000) note that in addition to the resources themselves, the organizational and strategic processes of firms are important because they facilitate the manipulation of resources into value-creating strategies. Empirical studies have mainly focused on the direct link between individual strands or configurations of resources and performance, while less attention has been devoted to how management can utilize these resources more effectively (Helfat 2000). Therefore, future research should focus not only on the resources (as has been done in the past), but also on how they are utilized. EO appears to be a useful construct for this purpose.

The environment appears to have complex relationships with small business growth. To some extent, this can explain inconsistencies in previous research. Among the environmental constructs examined, dynamism appears to be, by far, the most important both in terms of the current state and changes over time. Some of the complexity of the relationship between the environment and growth is 
captured through the strategic fit perspective. Based on our findings, it appears more relevant to consider EO and environmental dynamism simultaneously rather than separately. Furthermore, attitude in terms of goals, favored work tasks, expected consequences of growth, and growth intentions appears important to small business growth.

EO appears to be a very useful construct in understanding small business growth. A strong direct effect of EO on growth is consistent with previous findings. However, in addition to the direct effect, we also find that EO works as a conduit for other variables. All constructs included in the model are valuable in explaining EO. This suggests that the effect on growth of, for instance, certain attitudes is further fueled, if also combined with an entrepreneurial strategic orientation. Therefore, it appears particularly important to include EO in models striving to explain small business growth.

Examining the results at a more detailed level, the three constructs that have the strongest influence on growth are the growth attitude of the small business manager, the EO of the firm, and the dynamism of the task environment where the firm operates. Interestingly, these constructs are related to the individual, the firm, and the environment respectively. Thus, although growth is studied at the firm level, in order to explain these firm level outcomes, it is necessary to include explanatory variables from multiple levels.

One limitation of our study is the potential of reverse causality. For example, it may be that small businesses with high levels of EO mobilize resources differently than small businesses with low levels of EO, that is, EO effects the acquisition and utilization of resources. Managers of small businesses pursuing an EO strategy may put more emphasis on developing networks with other organizations in order to acquire information and source growth opportunities (Birley 1985; Johannisson 2000). These managers may also be more active in acquiring the substantial financial resources required for innovative efforts of their firm (Fildes 1990). Moreover, there is also the possibility that not only does an EO stimulate small business growth, but that growth in turn fosters the EO of a small business. For instance, growing sales lead to an increased inflow of cash for the small business, which the firm can use to pursue more innovative efforts, thereby stimulating EO. We believe that investigating these potential "feedback" effects would be a valuable extension of the model presented in this study.

Another limitation is that we included only a limited number of constructs in the model, and that these constructs were analyzed at an aggregate level. It was not the purpose of our study to subdivide them into their underlying components. However, some of these constructs have been elaborated on more finegrained in the literature. For example, with respect to network resources, our literature review shows that this construct can be divided into interorganizational, intraorganizational, and interpersonal networks. Moreover, the literature review also demonstrates that scholars have used more dimensions to describe the industrial and competitive environment of organizations, as we included in our model. One possible avenue for going forward researchers is to extend our model by taking a more fine-grained approach to (some of) the constructs we use in this study.

Acknowledgement The authors would like to thank two anonymous reviewers for their helpful comments.

\section{Appendix: Constructs and measures}

\section{Measures of small business growth}

\begin{tabular}{llc}
\hline Dimension & Questions & $\begin{array}{c}\text { Factor } \\
\text { Loadings }\end{array}$ \\
\hline $\begin{array}{l}\text { Employment growth } \\
\text { Sales growth }\end{array}$ & Current number of FTEs over number of FTEs previous year. & 70 \\
$\begin{array}{l}\text { Sales growth compared } \\
\text { to competitors }\end{array}$ & $\begin{array}{l}\text { This year's sales over last year's sales } \\
\text { Value growth compared } \\
\text { to competitors }\end{array}$ & $\begin{array}{l}\text { Has the market value of your firm increased or decreased relative } \\
\text { to your competitors over the past 12 month? Measured on 5-point scale }\end{array}$ \\
\hline
\end{tabular}


Appendix continued

Measures of entrepreneurial orientation

\begin{tabular}{|c|c|c|}
\hline Dimension & Opinions about two statements anchoring seven point scales & $\begin{array}{l}\text { Factor } \\
\text { Loadings }\end{array}$ \\
\hline Risk taking 1 & $\begin{array}{l}\text { Owing to the nature of the environment it is best to explore it gradually } \\
\text { via timid, incremental behavior versus Owing to the nature of the environment bold } \\
\text { ranging acts are viewed as useful and common practice }\end{array}$ & 21 \\
\hline Risk taking 2 & $\begin{array}{l}\text { Our firm has a strong proclivity for low risk projects (with normal and certain rates } \\
\text { of return) versus Our firm has a strong proclivity for high risk projects } \\
\text { (with chances of very high returns) }\end{array}$ & 45 \\
\hline Proactiveness 1 & $\begin{array}{l}\text { In our firm there is a strong tendency to follow competitors in introducing new } \\
\text { things and ideas versus In our firm we always try to be ahead competitors in product } \\
\text { novelty or speed of innovation and usually succeed }\end{array}$ & 55 \\
\hline Proactiveness 2 & $\begin{array}{l}\text { Our firm is characterized by the fact that we favour the tried and true versus Our firm is } \\
\text { characterized by the fact that we are growth, innovation, and development oriented }\end{array}$ & 71 \\
\hline Proactiveness 3 & $\begin{array}{l}\text { Our relationship to our competitors is characterized by the fact that we try to cooperate } \\
\text { and coexist with competitors versus Our relationship to our competitors is } \\
\text { characterized by the fact that we pursue a tough "undo-the-competitors" philosophy }\end{array}$ & 35 \\
\hline Innovativeness 1 & $\begin{array}{l}\text { In our firm there is a strong emphasis on } \mathrm{R} \& \mathrm{D} \text {, technological leadership and innovation } \\
\text { versus In our firm there is a strong emphasis on the marketing of true and tried } \\
\text { products or services }\end{array}$ & 50 \\
\hline Innovativeness 2 & $\begin{array}{l}\text { During the past } 3 \text { years our firm has marketed, excluding mere minor variations, no new } \\
\text { lines of products or services versus During the past } 3 \text { years our firm has marketed, } \\
\text { excluding mere minor variations, a very large number of new lines of products or } \\
\text { services }\end{array}$ & 65 \\
\hline Innovativeness 3 & $\begin{array}{l}\text { During the past } 3 \text { years, changes in product lines have been dramatic (e.g., changing } \\
\text { from mechanical to electric circulators) versus During the past } 3 \text { years, changes in } \\
\text { product lines have been of a minor nature (e.g., puttin in towel with the soap) }\end{array}$ & 63 \\
\hline
\end{tabular}

\section{Measures of environment}

\begin{tabular}{|c|c|c|}
\hline Dimension & Questions for Task Environment & $\begin{array}{l}\text { Factor } \\
\text { loadings }\end{array}$ \\
\hline $\begin{array}{l}\text { Dynamism } \\
\quad(5 \text { items; } \alpha=60)\end{array}$ & $\begin{array}{l}\text { To keep up with the markets and competitors at what rate must your firm change its } \\
\text { marketing practices? At what rate are products/services becoming obsolete in your } \\
\text { industry? To what extent is it difficult to predict the actions of competitors? } \\
\text { Consumer demand and tastes? To what extent have there been changes in product/ } \\
\text { service technology? Collected on seven point scales. }\end{array}$ & 100 \\
\hline $\begin{array}{l}\text { Hostility } \\
\qquad(4 \text { items; } \alpha=60)\end{array}$ & $\begin{array}{l}\text { How threatening is the environment? Is price competition? Is competition in product } \\
\text { innovations? Is dwindling price competition? Collected on seven point scales. }\end{array}$ & 100 \\
\hline Heterogeneity (1 item) & $\begin{array}{l}\text { To what extent is the nature of competition the same for our products? Collected on } \\
\text { seven point scales. }\end{array}$ & 100 \\
\hline $\begin{array}{l}\text { Change in dynamism } \\
\quad(3 \text { items; } \alpha=60)\end{array}$ & $\begin{array}{l}\text { Over the last } 3 \text { years, in your principal industry, to what degree has there been change } \\
\text { in growth opportunities in the environment? In the innovation of new operating } \\
\text { processes and new products and services? In research and development? }\end{array}$ & 100 \\
\hline $\begin{array}{l}\text { Change in hostility } \\
\qquad(2 \text { items; } \alpha=61)\end{array}$ & $\begin{array}{l}\text { Over the last } 3 \text { years, in your principal industry, to what degree has there been change } \\
\text { in the predictability of competitors' market activities? Change in the aggressiveness } \\
\text { of competitors' market activities? }\end{array}$ & 100 \\
\hline
\end{tabular}


Appendix continued

\begin{tabular}{|c|c|c|}
\hline Dimension & Questions for Task Environment & $\begin{array}{l}\text { Factor } \\
\text { loadings }\end{array}$ \\
\hline \multirow[t]{8}{*}{$\begin{array}{l}\text { Change in heterogeneity } \\
\text { (1 item) }\end{array}$} & $\begin{array}{l}\text { Over the last } 3 \text { years, in your principal industry, to what degree has there been change } \\
\text { in the needed diversity for production processes and marketing tactics to cater for } \\
\text { different customers? }\end{array}$ & 100 \\
\hline & Questions for Industry & \\
\hline & Percentage of turnover generated by three largest customers & 56 \\
\hline & Percentage of purchases from three largest suppliers & 26 \\
\hline & Percentage of sales from exports & 50 \\
\hline & Knowledge intensive manufacturing & 43 \\
\hline & Labour intensive manufacturing & 73 \\
\hline & Professional service sector & 31 \\
\hline
\end{tabular}

Measures of resources

\begin{tabular}{lll}
\hline Dimension & Items & $\begin{array}{l}\text { Regression } \\
\text { weights }\end{array}$ \\
\hline
\end{tabular}

Firm resources

How many full time equivalent employees does the firm have today? 25

How large do you expect your sales to be this year? 40

How many persons are in the management team? $\quad 31$

$\begin{array}{lr}\text { How many people in the firm have tertiary degrees? } & 9\end{array}$

How many people are on the board? -35

What percentage of the firm has been sold to new owners over the past 3 years? -33

The size of our firm (on a seven point scale) larger than most of our competitors or smaller than 9 most of our competitors.

The availability of capital during the past 3 years has been (on a seven point scale) insufficient and $\quad-39$ a great impediment for our development or fully satisfactory for the firm's development.

Important decisions that can be made by me or an employee are usually made by (on a seven point 16 scale) employee or myself.

$\begin{array}{lr}\text { How many external members are there on your board of directors? } & 8\end{array}$

Human capital

What is your highest level of completed education? $\quad 63$

Have many business or management courses have you taken? 36

$\begin{array}{ll}\text { Education in management or engineering } & 12\end{array}$

How many different firms have you worked for as a manager for longer than a year? 36

Approximately how many persons have you managed at one point in time? $\quad-10$

Have you even worked as a manager in a rapid growth firm (annual sales growth of at least 20\%) 26

$\begin{array}{ll}\text { What year did you become managing director of the firm? } & 13\end{array}$

What year were you born? $\quad-8$

Were you born in Sweden? 12

$\begin{array}{ll}\text { Gender (male) } & 35\end{array}$

Has anyone in your family ever started and then managed a firm? 36

Did you start the firm where you are currently CEO? 39

Have you ever started any other firm? $\quad 1$ 
Appendix continued

\begin{tabular}{|c|c|c|}
\hline Dimension & Items & $\begin{array}{l}\text { Regression } \\
\text { weights }\end{array}$ \\
\hline & $\begin{array}{l}\text { Before becoming CEO did you have experience from the same } \\
\text { industry? }\end{array}$ & -23 \\
\hline & $\begin{array}{l}\text { Are you at present associated with any other firm that you do not } \\
\text { personally run? }\end{array}$ & -15 \\
\hline \multicolumn{3}{|l|}{ Network resources } \\
\hline $\begin{array}{l}\text { Formal professional } \\
\text { advisors ( } 3 \text { items; } \alpha=67 \text { ) }\end{array}$ & $\begin{array}{l}\text { How important, as a source of ideas and advice when making } \\
\text { important decision are consultants? Lawyers? Regional } \\
\text { development fund and similar government support agencies? }\end{array}$ & 67 \\
\hline $\begin{array}{l}\text { Day-to-day advisors } \\
\quad(3 \text { items; } \alpha=61)\end{array}$ & $\begin{array}{l}\text { How important, as a source of ideas and advice when making } \\
\text { important decision is your chartered accountant? bank contact? } \\
\text { spouse and family? }\end{array}$ & -83 \\
\hline $\begin{array}{l}\text { Value chain advisors } \\
\qquad(3 \text { items; } \alpha=69)\end{array}$ & $\begin{array}{l}\text { How important, as a source of ideas and advice when making } \\
\text { important decision are your customers? suppliers? employees? }\end{array}$ & 49 \\
\hline Number of external board members & & -16 \\
\hline
\end{tabular}

\section{Measures of attitude}

\begin{tabular}{lll}
\hline Dimension & Items & $\begin{array}{l}\text { Regression } \\
\text { weights }\end{array}$ \\
& & \\
\hline
\end{tabular}

Goals

Creativity $(\alpha=70)$

How important is it to you that the firm makes possible that you have an outlet for your creativity? that you have the possibility for self-fulfillment?

Personal benefits $(\alpha=52)$

How important is it to you that the firm makes possible a high standard of living for you -17 and your family in financial terms? that you have enough time left for family and leisure activities? that the reap the benefits from your own work?

Stability $(\alpha=70)$

How important is it to you that the firm yields high profits? that you can control and -2 survey the firm's operations? that the firm is not overly dependent upon a small number of customers, suppliers, or lenders? that the firm is able to survive a crisis? That the firm's products and services are of high quality?

Power $(\alpha=50)$

How important is it to you that the firm makes possible that you gain a position in society? that you work independently and be independent from bosses? that you manage other people?

Sales growth

How important is it to you that the firm's sales increase?

How important is it to you that the firm's number of employees increases?

Favored work tasks

How much time would you like to spend on: Board work? Market plans? Development of strategies?

Marketing $(\alpha=79)$

How much time would you like to spend on: contacts with existing customers? Sales? Development of new customers?

Operations $(\alpha=58)$

How much time would you like to spend on: Calculating bids? Production? Purchasing? -50

Accounting $(\alpha=62)$

How much time would you like to spend on: Administration and finance? Performance 8 auditing? Bank relations? 
Table e continued

\begin{tabular}{lll}
\hline Dimension & Items & $\begin{array}{l}\text { Regression } \\
\text { weights }\end{array}$ \\
\hline
\end{tabular}

Expected consequences of growth

Work conditions $(\alpha=61) \quad$ What do you think your situation would be like if the firm was twice as big as it is today? Answered on a five point scale from considerably easier to considerably more difficult. In terms of devoting time at work to the work tasks you like the best? Managing the firm? Surveying and controlling the firm?

Firm characteristics $(\alpha=70)$ What do you think your situation would be like if the firm was twice as big as it is today? Answered on a five point scale from considerably easier to considerably more difficult. In terms of level of work required? In terms employee well-being at work? In terms of the amount of your personally "income" and other economic benefits? In terms of independence in your relations with customers, suppliers, and lenders? In terms of the firm's ability to survive a crises? In terms of high quality products and services? Do you think the firm would be worth more or less if sold? Five point scale from considerably more to considerably less.

Growth intentions

Sales growth

If the firm develops the way you would like it to, how large would you like sales to be

Employment growth for the firm in 5 years time?

If the firm develops the way you would like it to, how many employees would you like -15 to have in 5 years time?

\section{References}

Acs, Z. J., \& Audretsch, D. B. (1990). The determinants of small firm growth in US manufacturing. Applied Economics, 22, 143-153.

Aldrich, H. E., \& Auster, E. R. (1986). Even dwarfs started small: Liabilities of age and size and their strategic implications. Research in Organizational Behavior, 8, 165-198.

Alvarez, S. A., \& Busenitz, L. W. (2001). The entrepreneurship of resource-based theory. Journal of Management, 27, $755-775$.

Amabile, T. M. (1988). A model of creativity and innovation in organizations. Research in Organizational Behavior, 10, 123-169.

Andrews, K. R. (1987). The concept of corporate strategy. Burr Ridge, IL: Irwin.

Audretsch, D. B. (1995). Innovation and industry evolution. Cambridge, MA: MIT Press.

Audretsch, D. B., \& Feldman, M. P. (2003). Small firm strategic research partnerships: The case of biotechnology. Technology Analysis \& Strategic Management, 15, 273-288.

Audretsch, D. B., \& Mahmood, T. (1994). Firm selection and industry evolution: The post-entry performance of new firms. Journal of Evolutionary Economics, 4, 243-260.

Baldwin, J., \& Gellatly, G. (2003). Innovation strategies and performance in small firms. Cheltenham, UK: Edward Elgar.

Bamford, C. E., Dean, T. J., \& McDougall, P. P. (1997). Initial strategies and new venture growth: An examination of the effectiveness of broad vs. narrow breadth strategies. Frontiers of Entrepreneurship Research. Wellesley, MA: Babson College.
Bandura, A. (1986). Social foundations of thought and action: A social cognitive theory. Englewood Cliffs, NJ: PrenticeHall.

Bandura, A. (1991). Social cognitive theory of self-regulation. Organizational Behavior and Human Decision Processes, 50, 248-287.

Baum, J. A., Calabrese, T., \& Silverman, B. S. (2000). Don't go it alone: Alliance network composition and startup's performance in Canadian biotechnology. Strategic Management Journal, 21, 267-294.

Becker, G. S. (1975). Human Capital (2 ed.). Chicago: Chicago University Press.

Bellu, R. R., \& Sherman H. (1995). Predicting firm success from task motivation and attributional style. A longitudinal study. Entrepreneurship \& Regional Development, 7, 349-363.

Birley, S. (1985). The role of networks in the entrepreneurial process. Journal of Business Venturing, 3, 107-117.

Birley, S., \& Westhead, P. (1990). Growth and performance contrasts between 'types' of small firms. Strategic Management Journal, 2, 535-557.

Birley, S., \& Westhead, P. (1994). A taxonomy of business start-up reasons and their impact on firm growth and size. Journal of Business Venturing, 9, 7-31.

Bosna, N., van Praag, M., Thurik, R., \& de Wit, G. (2004). The value of human and social capital investments for the business performance of startups. Small Business Economics, 23, 227-236.

Brown, S. L., \& Eisenhardt, K. M. (1995). Product development: Past research, present findings, and future directions. Academy of Management Review, 20, 342-378.

Brüderl, J., \& Preisendörfer, P. (1998). Network support and the success of newly founded businesses. Small Business Economics, 10, 213-225. 
Brush, C. G., Greene, P. G., Hart, M., \& Edelman, L. (1997). Resource configurations over the life cycle of ventures. Frontiers of Entrepreneurship Research. Wellesley, MA: Babson College.

Carroll, G. R., \& Hannan, M. T. (2000). The demography of corporations and industries. Princeton, New Jersey: Princeton University Press.

Castrogiovianni, G. J. (1996). Pre-start-up planning and the survival of new small firms. Journal of Management, 22, 801-823.

Chandler, G. N., \& Hanks, S. H. (1994a). Founder competence, the environment, and venture performance. Entrepreneurship Theory and Practice, 18, 77-89.

Chandler, G. N., \& Hanks, S. H. (1994b). Market attractiveness, resource-based capabilities, venture strategies, and venture performance. Journal of Business Venturing, 9, 331-349.

Cohen, W. M., \& Levinthal, D. A. (1990). Absorptive capacity: A new perspective on learning and innovation. Administrative Science Quarterly, 35, 128-152.

Connor, K. (1991). A historical comparison of resource-based theory and five schools of thought within industrial organization economics. Journal of Management, 17, 121-154.

Cooper, A. C., Gimeno-Gascon, F. J., \& Woo, C. Y. (1994). Initial human and financial capital as predictors of new venture performance. Journal of Business Venturing, 9, 371-395.

Cooper, A. C., Folta, T. B., \& Woo, C. Y. (1995). Entrepreneurial information search. Journal of Business Venturing, 10, 107-120.

Covin, J. G., \& Covin, T. J. (1990). Competitive aggressiveness, environmental context, and small firm performance. Entrepreneurship Theory and Practice, 13, 35-50.

Covin, J. G., \& Slevin, D. P. (1989). Strategic management of small firms in hostile and benign environments. Strategic Management Journal, 10, 75-87.

Covin, J. G., \& Slevin, D. P. (1990). New venture strategic posture, structure, and performance: an industry life cycle analysis. Journal of Business Venturing, 5, 123-135.

Covin, J. G., \& Slevin, D. P. (1991). A conceptual model of entrepreneurship as firm behavior. Entrepreneurship Theory and Practice, 16, 7-25.

Covin, J. G., \& Slevin, D. P. (1993). A response to Zahra's 'critique and extension of the Covin-Slevin entrepreneurship model'. Entrepreneurship Theory and Practice, 17, 23-28.

Cressy, R. (2006) .Why do most firms die young? Small Business Economics, 26, 103-116.

Cromie, S., Birley, S., \& Callaghan, I. (1994). Community brokers: Their role in the formation and development of business ventures. In: J. M Veciana (Ed.), SMEs: Internationalization, networks and strategy. Hampshire, U. K: Avebury.

Cyert, R. M., \& March, J. G. (1963). A behavioral theory of the firm. Englewood Cliffs, NJ: Prentice-Hall.

Davidsson, P. (1989a). Continued entrepreneurship and small firm growth. Stockholm: Stockholm School of Economics.

Davidsson, P. (1989b). Entrepreneurship - and after? A study of growth willingness in small firms. Journal of Business Venturing, 4, 211-226.
Davidsson, P. (2004). Researching entrepreneurship. Boston, MA: Springer.

Davidsson, P., \& Honig, B. (2003). The role of social and human capital among nascent entrepreneurs. Journal of Business Venturing, 18, 301-331.

Davidsson, P., \& Wiklund, J. (2000). Conceptual and empirical challenges in the study of firm growth. In: D. Sexton \& H. Landström (Eds.), The Blackwell handbook of entrepreneurship (pp. 26-44). Oxford, MA: Blackwell.

Davidsson, P., \& Wiklund, J. (2001). Level of analysis in entrepreneurship research: Current practice and suggestions for the future. Entrepreneurship Theory and Practice, 25, 81-99.

Davidsson, P., Delmar, F., \& Wiklund, J. (2002). Entrepreneurship as growth; growth as entrepreneurship. In: M. A. Hitt, R. D. Ireland, S. M. Camp, \& D. L. Sexton (Eds.), Strategic entrepreneurship: Creating a new mindset. Oxford: Blackwell Publishing.

DeCarolis, D. M., \& Deeds, D. L. (1999). The impact of stocks and flows of organizational knowledge on firm performance. An empirical investigation of the biotechnology industry. Strategic Management Journal, 20, 953-968.

Delmar, F. (1996). Entrepreneurial behavior and business performance. Stockholm: Stockholm School of Economics.

Delmar, F. (1997). Measuring growth: Methodological considerations and empirical results. In: R. Donckels \& A. Miettinen (Eds.), Entrepreneurship and SME research: On its way to the next millenium (pp. 190-216). Aldershot, VA: Avebury.

Douglas, E., \& Shepherd, D. A. (2000). Entrepreneurship as a utility maximizing response. Journal of Business Venturing, 15, 393-410.

Eagly, A. H., \& Chaiken, S. (1993). The psychology of attitudes. Orlando, FLA: Harcourt Brace Jonanovich, Inc.

Eisenhardt, K. M., \& Bourgeois, L. J. (1988). Politics of strategic decision making in high-velocity environments: Toward a midrange theory. Academy of Management Journal, 31, 737-770.

Eisenhardt, K. M., \& Schoonhoven, C. B. (1990). Organizational growth: Linking founding team, strategy, environment, and growth among US semiconductor ventures. Administrative Science Quarterly, 35, 504-529.

Eisenhardt, K. M., \& Martin, J. A. (2000). Dynamic capabilities: What are they. Strategic Management Journal, 21, 1105-1121.

Ensley, M. D., Pearson, A. W., \& Amason, A. C. (2002). Understanding the dynamics of new venture top management teams: Cohesion, conflict, and new venture performance. Journal of Business Venturing, 17, 365-386.

Ensley, M. D., Pearson, A. W., \& Pierce, C. L. (2003). Top management team process, shared leadership, and new venture performance: A theoretical model and research agenda. Human Resource Management Review, 13, 329-346.

Falk, R. F., \& Miller, N. B. (1992). A primer for soft modeling. Akron, Ohio: University of Akron.

Fildes, R. A. (1990). Strategic challenges in commercializing biotechnology. California Management Review, 32, 6372. 
Fornell, C., \& Bookstein, F. L. (1982). Two structural equation models: lisrel and pls applied to consumer exit-voice theory. Journal of Marketing Research, XIX, 440-452.

Fornell, C., Lorange, P., \& Roos, J. (1990). The cooperative venture formation process: A latent variable structural modeling approach. Management Science, 36, 12461255 .

Fuller, T., \& Moran, P. (2001). Small entreprises as complex adaptive systems: A methodological question? Entrepreneurship and Regional Development, 13, 47-63.

Granovetter, M. (1985). Economic action and social structure: The problem of embeddedness. American Journal of Sociology, 91, 481-510.

Grant, R. M. (1991). The resource-based theory of competitive advantage: Implications for strategy formulation. California Management Review, 33, 114-135.

Greene, P., \& Brown, T. (1997). Resource needs and the dynamic capitalism typology. Journal of Business Venturing, 12, 161-173.

Greve, W. (2001). Traps and gaps in action explanation: Theoretical problems of a psychology of human action. Psychological Review, 108, 435-451.

Gruber, T. R. (1993). A translation approach to portable ontologies. Knowledge Acquisition, 5, 199-220.

Hamel, G. (2000). Leading the revolution. Cambridge, MA: Harvard University Press.

Hartarska, V., \& Gonzalez-Vega, C. (2006). What affects new and established firms' expansion? Evidence from small firms in Russia. Small Business Economics, 27, 195-206.

Helfat, C. E. (2000). Guest editor's introduction to the special issue: The evolution of firm capabilities. Strategic Management Journal, 21, 955-959.

Higgins, M. C., \& Gulati, R. (2006). Stacking the deck: The effect of top management team backgrounds on investor decisions. Strategic Management Journal, 27, 1-25.

Hulland, J. (1999). Use of partial least squares (PLS) in strategic management research: A review of four recent studies. Strategic Management Journal, 20, 195-204.

Johannisson, B. (2000). Networking and entrepreneurial growth. In: D. Sexton \& H. Landström (Eds.), The Blackwell handbook of entrepreneurship (pp. 26-44). Oxford, MA: Blackwell.

Kets de Vries, M. F. R., Miller, D., \& Noel, A. (1993). Understanding the leader-strategy interface: Application of the strategic relationship interview model. Human Relations, 46, 5-22.

Kim, P. A., Aldrich, H. E., \& Keister, L. A. (2006) Access (not) denied: The impact of financial, human, and cultural capital on entrepreneurial entry in the United States. Small Business Economics, 27, 5-22.

Khan, A. M. (1986). Entrepreneur characteristics and the prediction of new venture success. Omega ,14, 365-372.

Koeller, C. T., \& Lechler, T. G. (2006). Economic and managerial perspectives on new venture growth: An integrated analysis. Small Business Economics, 26, 427-437.

Kogut, B., \& Zander, U. (1992). Knowledge of the firm, combinative capabilities, and the replication of technology. Organization Science, 3, 383-397.

Kolvereid, L. (1992). Growth aspirations among Norwegian entrepreneurs. Journal of Business Venturing, 7, 209-222.
Kolvereid, L., \& Bullvåg, E. (1996). Growth intentions and actual growth: The impact of entrepreneurial choice. Journal of Enterprising Culture, 4, 1-17.

Kor, Y. Y. (2003). Experience-based top management team competence and sustained growth. Organization Science, 14, 707-719.

Lerner, J., \& Merges, R. P. (1998). The control of technology alliances: An empirical analysis of the biotechnology industry. Journal of Industrial Economics, 46, 125-156.

Lewin, R., \& Regine, B. (1999). The soul at work: Unleasing the power of complexity science for business success. London: Orion Business.

Locke, E. A. (1991). The motivation sequence, the motivation hub, and the motivation core. Organizational Behavior and Human Decision Processes, 50, 288-299.

Locke, E. A., \& Latham, G. P. (1990). Work motivation and satisfaction: Light at the end of the tunnel. Psychological Science, 1, 240-247.

Lumpkin, G. T., \& Dess, G. G. (1996). Clarifying the entrepreneurial orientation construct and linking it to performance. Academy of Management Review, 21, $135-172$.

Madsen, E. L. (2007). The significance of sustained entrepreneurial orientation on performance of firms - A longitudinal analysis. Entrepreneurship and Regional Development, 19, 185-204.

March, J. G. (1991). Exploration and exploitation in organizational learning. Organization Science, 2, 71-87.

McGrath, R. G. (2001). Exploratory learning, innovative capacity, and managerial oversight. Academy of Management Journal, 44, 118-131.

McGrath, R., Tsai, M., Venkataraman, S., \& MacMillan, I. (1996). Innovation, competitive advantage and rent: A model and test. Management Science, 42, 389-403.

Miller, D. (1983). The correlates of entrepreneurship in three types of firms. Management Science, 29, 770-791.

Miller, D. (1987). Strategy making and structure: Analysis and implication for performance. Academy of Management Journal, 30, 7-32.

Miller, D. (1988). Relating Porter's business strategies to environment and structure: Analysis and performance implications. Academy of Management Journal, 31, 280-308.

Miller, D., \& Friesen, P. H. (1978). Archetypes of strategy formulation. Management Science, 24, 921-933.

Miller, D., \& Friesen, P. H. (1982). Innovation in conservative and entrepreneurial firms: Two models of strategic momentum. Strategic Management Journal, 3, 1-25.

Miner, J. B. (1990). Entrepreneurs, high growth entrepreneurs, and managers: contrasting and overlapping motivational patterns. Journal of Business Venturing, 5, 221-234.

Miner, J. B., Smith, N. R., \& Bracker, J. S. (1989). Role of entrepreneurial task motivation in the growth of technologically innovative firms. Journal of Applied Psychology, 74, 554-560.

Miner, J. B., Smith, N. R, \& Bracker, J. S. (1994). Role of entrepreneurial task motivation in the growth of technologically Innovative firms: interpretations from follow-up data. Journal of Applied Psychology, 79, 627-630. 
Naffziger, D. W., Hornsby, J. S., \& Kuratko, D. S. (1994). A proposed research model of entrepreneurial motivation. Entrepreneurship Theory and Practice, 18, 29-42.

Namen, J. L., \& Slevin, D. P. (1993). Entrepreneurship and the concept of fit: A model and empirical tests. Strategic Management Journal, 14, 137-153.

Pelham, A. M., \& Wilson, D. T. (1996). A longitudinal study of the impact of market structure, firm structure, strategy, and market orientation culture on dimensions of smallfirm performance. Journal of the Academy of Marketing Science, 24, 27.

Penrose, E. (1959). The theory of the growth of the firm. Oxford: Oxford University Press.

Powell, W. W., Koput, K. W., \& Smith-Doerr, L. (1996). Interorganizational collaboration and the locus of innovation: Networks of learning in biotechnology, Administrative Science Quarterly, 41, 116-145.

Roper, S. (1999). Modeling small business growth and profitablity. Small Business Economics, 13, 235-252.

Rothaermel, F. T., \& Deeds, D. L. (2004). Exploration and exploitation alliances in biotechnology: A system of new product development. Strategic Management Journal, 25, 201-221.

Rumelt, R. P. (1987). Theory, strategy, and entrepreneurship. In: D. J. Teece (Ed.), The competitive challenge (pp. 137158). Cambridge, MA: Ballinger.

Schumpeter, J. (1934). The theory of economic development. Cambridge: MA: Harvard University Press.

Sexton, D., \& Bowman-Upton, N. (1987). A growth model of the firm based on market, owner, and strategic factors. In: G. Hills (Ed.), Research in the marketing/entrepreneurship interface. Marietta, GA: USASBE.

Sexton, D., \& Bowman-Upton, N. (1991). Entrepreneurship: creativity and growth. New York: Macmillan.

Shane, S. (2000). Prior knowledge and the discovery of entrepreneurial opportunities. Organization Science, 11, 448-469.

Stevenson, H. H., \& Gumpert, D. E. (1985). The heart of entrepreneurship. Harvard Business, Review, 85-94.

Stevenson, H. H., \& Jarillo, J. C. (1986). Preserving entrepreneurship as companies grow. Journal of Business Strategy, 6, 10-23.

Stevenson, H. H., \& Jarillo, J. C. (1990). A paradigm of entrepreneurship: Entrepreneurial management. Strategic Management Journal, 11, 17-27.

Storey, D. J. (1994). Understanding the small business sector. London: Routledge.

Storey, D. J. (1996). The ten percenters. London: Deloitte \& Touche.

Storey, D. J. (1997). The ten percenters second report. London: Deloitte \& Touche.

Teece, D. J., Pisano, G., \& Shuen, A. (1997). Dynamic capabilities and strategic management. Strategic Management Journal, 18, 509-533.

Venkataraman, S. (1997). The distinctive domain of entrepreneurship research: An editor's perspective. In: J. Katz \&
R. Brockhaus (Eds.), Advances in entrepreneurship, firm emergence, and growth, vol. 3 (pp. 119-138). Greenwich, CT: JAI Press.

Vivarelli, M., \& Audretsch, D. B. (1998). The link between the entry decision and post-entry performance: Evidence from Italy. Industrial and Corporate Change, 7, 485-500.

Weinzimmer, L. G., Nystrom P. C., \& Freeman, S. J. (1998). Measuring organizational growth: Issues, consequences, and guidelines. Journal of Management, 24, 235-262.

Wiklund, J. (1998). Small firm growth and performance: Entrepreneurship and beyond. Jönköping: Jönköping International Business School.

Wiklund, J. (1999). The sustainability of the entrepreneurial orientation - performance relationship. Entrepreneurship Theory \& Practice, 24, 37-48.

Wiklund, J., \& Shepherd, D. A. (2003a). Knowledge-based resources, entrepreneurial orientation, and the performance of small and medium sized businesses. Strategic Management Journal, 24, 1307-1314.

Wiklund, J., \& Shepherd, D. A. (2003b) Aspiring for, and achieving growth: The moderating role of resources and opportunities. Journal of Management Studies, 40, 1919-1942.

Wiklund, J., \& Shepherd, D. A. (2005). Entrepreneurial orientation and small business performance: A configurational approach. Journal of Business Venturing, 20, 71-91.

Wiklund, J., Davidsson, P., \& Delmar, F. (2003). What do they think and feel about growth: An expectancy-value approach to small business managers' attitudes toward growth. Entrepreneurship Theory and Practice, 20, 247-270.

Zahra, S. (1991). Predictors and financial outcomes of corporate entrepreneurship: An explorative study. Journal of Business Venturing, 6, 259-285.

Zahra, S. (1993). Environment, corporate entrepreneurship, and financial performance: A taxonomic approach. Journal of Business Venturing, 8, 319-340.

Zahra, S., \& Covin, J. (1995). Contextual influence on the corporate entrepreneurship-performance relationship: A longitudinal analysis. Journal of Business Venturing, 10, 43-58.

Zahra, S., \& Bogner, W. C. (2000). Technology strategy and software new ventures' performance: Exploring the moderating effect of the competitive environment. Journal of Business Venturing, 15, 135-173.

Zahra, S., Sapienza, H. J., \& Davidsson, P. (2006). Entrepreneurship and dynamic capabilities: A review, model, and research agenda. Journal of Management Studies, 43, 917-955.

Zucker, L. G., Darby, M. R., \& Armstrong, J. S. (2002). Commercializing knowledge: University science, knowledge capture, and firm performance in biotechnology. Management Science, 48, 138-153. 